\title{
Music and Politics on Disc, 2007
}

\section{DEREK KATZ}

As was the case last year, this list pretends to be nothing more than a survey of some recordings connected in some way to the intersection of music and politics, making no claims to be either comprehensive or representative. The list is exclusively (and unfairly) devoted to art music, and (again, unfairly) slanted towards music of the $20^{\text {th }}$ and $21^{\text {st }}$ centuries. My hope, though, is that the list will be sufficient eclectic to bring items of interest to the attention of those who otherwise not have been aware of them, and to offer some suggestions about the different ways in which recorded sonic and visual material can reflect both musical and societal concerns.

There continues to be a small, but steady, flow of recordings of works with explicit and topical political messages. Neil Rolnick's Playing Well with Others is a parable in the style of Dr. Suess about two boys who bully and insist on making the rules. In case the referents aren't sufficiently transparent, the boys are named "Georgie" and "Dickie"(INNOVA656). Another recent INNOVA disc contains Alexandra Gardner's electro-acoustic work Ayehli, which, although composed during a residency in Barcelona, contains samples of sounds from the areas around New York's Ground Zero (INNOVA662). Composers also continue to set texts that have political content or seem to have been chosen for polemical purposes. New recordings of old works include Stefan Wolpe's 1950 Excerpt from Dr. Einstein's Address about Peace in the Atomic Era, performed by Patrick Mason and Robert Shannon (Bridge BRIDGE9209), while Rory Boyle's 2004 setting of Dylan Thomas' WWII "Ceremony after a Fire Raid" is a newer work based on an older poem, found on a recital disc of Scottish trumpet music performed by Mark O'Keefe (Delphian DCD34049). The political content of another, much more famous, older work, Gorecki's Symphony No. 3, is made more explicitly manifest in Tony Palmer's film The Symphony of Sorrowful Songs, which contains documentary footage, both from Polish concentration camps, and from more recent examples of terrible suffering from around the world (Voiceprint Records TPDVD102). There are also instrumental works inspired by songs or texts, like Aaron Jay Kernis' Meditation (In memoriam for John Lennon), with musical references to Lennon's "Imagine” (Black Box BBM1107), Christos Tsitsaros' Dramatic Variations after a reading of Primo Levi's 'Survival in Auschwitz,' for solo piano (Centaur CRC2856) and Justin Dello Joio's piano trio The March of Folly, inspired by Barbara Tuchman (Bridge BRIDGE9220).

Critical moments in social history frequently crop up as operatic backdrops. One such rarity which is only now properly available on CD is Donizetti's last opera, Dom Sébastian, roi de Portugal, a spectacular tale of the Spanish Inquisition composed for the Paris Opéra. A new recording from Covent Garden uses Mary Ann Smart's 2003 critical edition (Opera Rara ORC33). From Donizetti's final opera we can jump to Penderecki's first, Die Teufel von Loudon, about ecclesiastical intrigue in $17^{\text {th }}$ century France, now available in a film from Hamburg (ArtHaus Musik 101 279). Opera has also long provided opportunities for political implications. Karl Amadeus Hartmann's Simplicius Simplicissimus, composed “for the drawer” between 1934 and 1935, uses 


\section{Music AND Politics Winter 2008}

the Thirty Years' War as a commentary for the German wars of the $20^{\text {th }} \mathrm{C}$. A production from the Stuttgart Staatsoper is now on DVD (ArtHaus Musik 101 255).

Music can also be connected to political events by virtue of the circumstances of their composition and performance. The Chapel Royal Choir has produced a disc of music that may have been performed at the 1685 coronation of James II, including works by Blow, Purcell and Tallis (Signum Classics SUGCD094), while the Ricercar Consort has assembled a Bach program occasioned by the 1727 death of Christiane Eberhardine, Queen of Poland (Mirare MIR030). Paisiello's La Daunia felice is an allegory composed for a 1797 Bourbon wedding in Naples, under the threat of Napoleon's troops (Dynamic CDS516). These tributes, though, hardly ceased in the $18^{\text {th }}$ century. The eighth of Peter Maxwell Davies' ten Naxos Quartets, newly recorded by the Maggini Quartet, was dedicated to the Queen for her 80 $0^{\text {th }}$ birthday (Naxos 8 557399).

There have also been a number of releases of music by composers whose lives were affected by war. Anne Sofie von Otter and Christian Gerharer have recorded an opulent tribute to the composers of the Terezin concentration camp (Deutsche Grammophon DG 477 6546GH, available March 25, 2008 in the U.S.), and Herbert Henck has recorded piano works by Norbert von Hannenheim and Ludwig Trepulka, students of (respectively) Schoenberg and Hauer. Hannenheim, although previously believed to be a victim of an Allied air raid in 1945, probably died in a Berlin psychiatric hospital, and Trepulka went missing in action with the German army the same year (ECM New Series 476 5276). Rudi Stefan was only 28 when he was killed by a Russian sniper in 1915, but had a completed an opera, Die ersten Menschen, which had been accepted for performance by the Frankfurt opera. A new CD preserves a live concert performance from the French National Orchestra, unfortunately with substantial cuts (Naïve V5028). Moisey Weinberg survived the second world war in the Soviet Union, but was imprisoned in the wake of the 1948 resolution that also led to banning of Shostakovich's sixth, eighth and ninth symphonies. Three of his war-time works (the Klezmer-inflected clarinet sonata, the piano quintet and the Jewish Songs) get the major label treatment on RCA (RCA Red Seal 82876-87769-2).

Moving to somewhat more attenuated relationships between music and politics, there have also been recordings of music more loosely connected to important moments in cultural history. Pare Lorentz's New Deal documentaries The Plow the Broke the Plain and The River, with soundtracks by Virgil Thomson, are now on a Naxos DVD (2110521), and Lou Harrison's Mass for St. Celilia's Day reflects the composer's reactions to the Second Vatican Council (Kleos KLS5141). Many works are the product of nationalist impulses of various sorts. Amongst the less usual suspects is Fredrik Pacius's 1852 Singspiel The Hunt of King Charles, generally considered to be the first Finnish opera (Marco Polo 8 225317/18).

Finally, some discs seem to be making a polemical point by virtue of the repertoire contained on them. Catherine Bott's recital of songs from Medieval Andulusia (the first disc from the London art dealer and art-rock afficionado Fred Mann), with its mixture of Christian and Islamic texts and influences is difficult to hear without regarding it as a rueful commentary on recent events (Fred Music FREDCD1), while the Britten Sinfonia's tribute to the New York street musician Moondog (he's the one in the Viking outfit) must surely be trying to tell us something about music and society (SoundCircus SC010). 